\title{
Landslide Hazard and Risk Management (WCoE 2014-2017)
}

\author{
Josef Stemberk, Vít Vilímek, Jan Klimeš, Jan Blahůt, Filip Hartvich, \\ and Jan Balek
}

\begin{abstract}
The World Centre of Excellence (WCoE) on Landslide Risk Reduction entitled "Landslide risk assessment and development guidelines for effective risk reduction" (2014-2017) was designed to contribute to the risk reduction effort formulated in the Sendai Partnership initiative. Several research activities were developed and their results were presented to a broad public through a series of articles, informative web pages and documentary movies. The research focused on improving landslide hazard assessment in a variety of natural environments, including deep-seated as well as shallow landslides. Landslide hazard assessment was applied practically through development projects in Ethiopia and Peru. Within the scope of the WCoE we proposed and conducted two projects of the International Program on Landslides (IPL). One of them is dedicated to compilation and analysis of glacial lake outburst floods (Database of glacial lake outburst floods (GLOFs)-project No. 179) at the global level. This potentially highly damaging natural phenomenon combines characteristics of floods and debris flows and often also involves landslides in the initiation process. The other IPL project focuses on the main challenges of landslide risk reduction in the Czech Republic (Challenges for landslide hazard and risk management in "low risk" regions, Czech Republic, IPL project No. 197), which is a country with abundant landslide-related knowledge and rather low annual occurrence frequencies. Despite that, landslides cause considerable damage and financial losses, which often could be prevented if the available hazard information were to be used.
\end{abstract}

\section{Keywords}

Risk reduction • Landslide hazard • Development projects • Peru • Ethiopia • Czech republic

J. Stemberk · J. Klimeš $(\bowtie) \cdot$ J. Blahůt $\cdot$ F. Hartvich $\cdot$ J. Balek Czech Academy of Sciences, Institute of Rock Structure \&

Mechanics, Prague, 182 09, Czech Republic

e-mail: klimes@irsm.cas.cz

J. Stemberk

e-mail: stemberk@irsm.cas.cz

J. Blahůt

e-mail: blahut@irsm.cas.cz

F. Hartvich

e-mail: hartvich@irsm.cas.cz

J. Balek

e-mail: balek@irsm.cas.cz

\section{Vilímek}

Department of Physical Geography and Geoecology, Charles University, Prague, 128 43, Czech Republic

e-mail: vilimek@natur.cuni.cz

\section{Landslide Research for Better Hazard and Risk Assessment}

\section{Deep-Seated Landslide Monitoring for Improved Hazard Assessment}

Deep-seated landslides often act as precursors to episodic and potentially catastrophic movements (Pánek and Klimeš 2016). Because of the poor strength and unfavourable hydrological characteristics of mobilized material, they may represent significant obstacles for infrastructure development (Pánek et al. 2014). Monitoring of this phenomenon requires very precise and robust instruments which allow for precise and long-term movement recordings. For this purpose our 
research team developed (Košt’ák 1969) and improved (Klimeš et al. 2012; Rowberry et al. 2016) a very precise, optical-mechanical crack gauge, which records displacement in three dimensions along pre-defined surfaces of ruptures. Study sites equiped with this instrument are located mainly within the Czech and Slovak Republic: (https://www.irsm. cas.cz/ext/tecnet/index_en.php?page=google_mapa_sesuv_en).

Long term monitoring of deep-seated rockslides in a flysh rock complex (Stemberk et al. in press) revealed coupling between landslide creep and tectonic activities. These deformations contribute to a weakening of rock strength along the planes of rupture and thus may contribute to possible future episodic activity of deep-seated landslides.

A fully automated deformation monitoring system with remote access was established on El Hierro Island, Spain (Fig. 1). Its goal is to record possible movement activity of incipient deep-seated landslides, where we so far have recorded creep movement of the order of $1 \mathrm{~mm} \mathrm{yr}^{-1}$ (Klimeš et al. 2016a, b). Recently, a "big data" approach has been used to improve interpretation of the detected movements, by considering a number of environmental factors which may affect the detected movements (Blahůt et al. submitted).

Possible gravitational or tectonic deformations at the scale of alpine ridges are monitored within the Large Scale Monitoring (LASMO) project at the Grimsel Test Site (Switzerland), dedicated to the long-term management of underground radioactive waste disposal. In this case, precise detection of very slow rock deformation is required and is provided by the TM71 crack gauge.

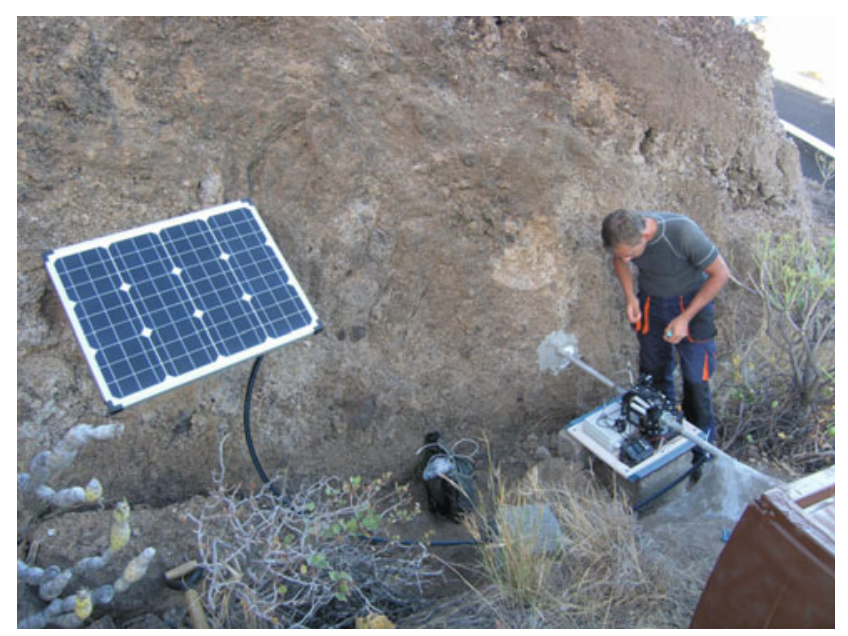

Fig. 1 One of the monitoring sites on the El Hierro Island, Canary Archipelago, Spain. The automatic crack gauge (in front of the person) records movements along a side scarp of the San Andrés deep-seated landslide

\section{Landslide Hazard in High Mountains and Arctic Regions}

Landslides in high mountains may initiate potentially dangerous outburst floods from glacial lakes. Their ability to do so largely depends on their size (volume) and the location of impact point into the lake with respect to the lake outflow. We investigated in depth landslides from side moraines as possible triggers of outburst flood at the Palcacocha Lake, Cordillera Blanca, Peru. The results of slope stability calculations, and models of impact wave propagation, as well as landslide movement detection using satellite radar interferometric analyses, allowed a reliable assessment of hazards related to the outburst floods at this specific site under current conditions (Klimeš et al. online first). The effects of different types of slope movements on glacial lake outburst flood (GLOF) initiation are also included in the susceptibility assessment methods tailored for the Cordillera Blanca Mts. (Emmer and Vilímek 2014). Research on the world-wide patterns of GLOF occurrences and characteristics is further supported by maintaining and improving the GLOF world wide database within the scope of the IPL project entitled "Database of glacial lake outburst floods (GLOFs) - project No. 179" (Emmer et al. 2016).

Rock slope development in the High Arctic (SW Spitsbergen, Norway) was described using several dating and geomorphological methods, while recent rock deformations are being monitored with dilatometers. The monitoring results are applied to the assessment of future possible hazards related to arctic rock slopes affected by climate and environmental change expressed by glacier retreat.

\section{Precipitations as a Landslide Trigger}

Case studies in the Czech Republic were used to investigate the relationship between precipitation and debris flow inititation or landslide movement activity. For debris flows that developed in 2010 in granitic mountains, the research concluded that high amounts of antecendent precipitation, as well as high-intensity short-duration precipitation, were required to initiate the flows (Smolíková et al. 2016). The importance of coupling of high ground water levels and short-term high-intensity precipitation for shallow landslide movement acceleration is illustrated by long-term monitoring of near-surface movements of a shallow landslide in Cretaceous sedimentary rocks (W. Bohemia, Czech Republic). The landslide underwent several major movement reactivations, destroying a railroad and local road. The monitoring includes two extensometric profiles measured 
with manual tape, with extensometer and several piesometers and boreholes where the ground water level is monitored. Results since 1994 show that the major movement accelerations occured during periods with extremly high ground water levels.

\section{Improving Public Landslide Risk Awareness, Czech Republic}

Czech Republic has a well developed and up-to date national landslide inventory, as well as a methodology for landslide hazard assessment. Regions highly prone to landslide occurence that have been subjected to several catastrophic landslide events during the last 20 years are also well described. Despite that, landslides repeatedly cause significant damage to infrastructure and incur considerable costs. We asume that one reason is that the general public and responsible authorities do not pay corresponding attention to this potentially damaging phenomenon. To increase awareness about landsliding especially among authorities, we summarized the costs of landslide-related construction and mitigation works claimed in public budgets. These expenses represent the true costs related to landslide occurrence and reactivations and are based on publically available databases which cover the whole territory of the Czech Republic. Therefore this approach represents an objective way to obtain comparable data about expenses related to landslide mitigation works. These data have not been evaluated yet. Resulting annual landslide-related costs do not include all of the expenses but we are convinced that the most costly mitigation works are included. Analysis of the data confirm the high overall costs related to landslides and their uneven distribution within the territory of the Czech Republic.

\section{Application and Dissemination of Landslide Hazard and Risk Assessment Research}

\section{Development Cooperation Projects in Ethiopia and Peru}

Dissemination of knowledge about landslide hazards and risk assessment on an international level was carried out through projects funded by the Czech Development Cooperation agency. The first one is cooperation with the University of Arba Minch in Ethiopia. The project is focused on teaching (Fig. 2) and field training of undergraduate students in engineering geology, geotechnics and hydrogeology, with special attention to landslide mapping, monitoring and hazard assessment. The final goal of the project is to establish and help to maintain a research center dedicated

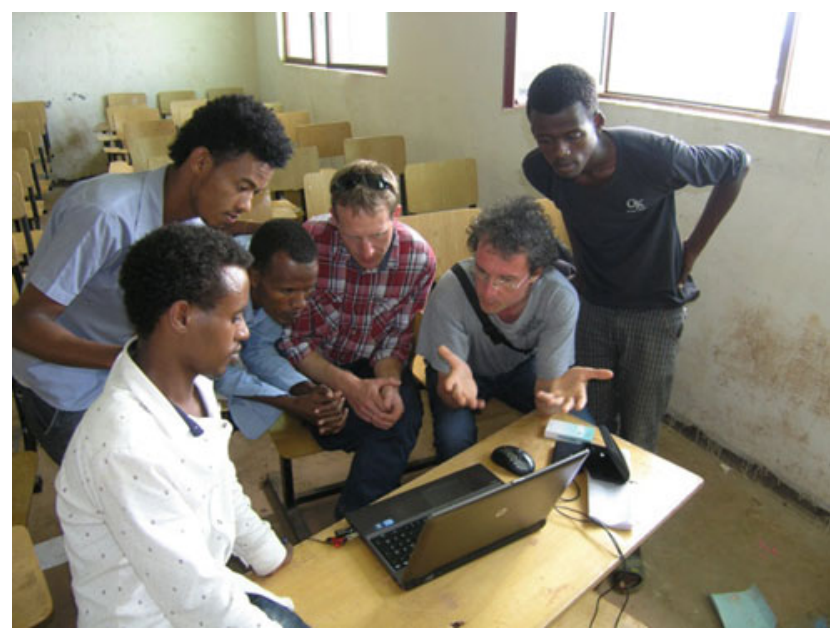

Fig. 2 Close interaction between students and teachers during preparation of thesis works, Arba Minch University, Ethiopia

to hazardous geological processes at the Arba Minch University. This development project takes advantage of the number of research works previously conducted in the landslide-prone regions of Ethiopia (Vařilová et al. 2015). This work points out the importance of the combined negative effects of annual intensive precipitation during rainy seasons and human activities on landslide reactivation and occurence. It also suggests possible measures to reduce the landslide hazard and risk that are applicable to the local technical and social conditions.

Another development project was conducted in Peru to implement measures for landslide risk reduction in the village of Rampac Grande (Carhuaz, Ancash). This village has been endangered since 2009 by an active landslide with a high potential for damage. The project follows previously conducted research (Vilímek et al. 2016; Klimeš and Vilímek 2011) and was conducted by Peruvian research institute INAIGEM (Instituto Nacional de Investigación en Glaciares y Ecosistemas de las Montaña), with the collaboration of Czech researchers. The one-year project involved a series of meetings with local authorities and inhabitants during all of its stages. Thanks to the open and repeated interactions with the local people, the project was accepted by the local inhabitants who previously were highly suspicious of any research activity around their village (Klimeš and Vilímek 2011).

The project results include a landslide hazard map and posting of signs showing evacuation routs and construction of two monitoring extensometric profiles. All the project results were presented to the local population (Fig. 3). The purpose and technique of tape extensometric monitoring was explained in the field (Fig. 4). The close communication of all project steps to the local population is a crucial requirement for its success and long-term sustainability. 


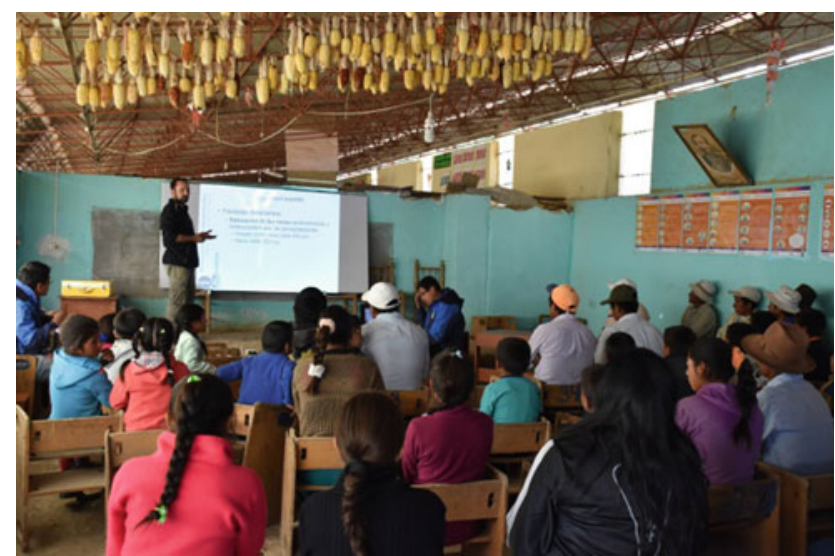

Fig. 3 Project results were presented at the local school to the village authorities as well as school students and teachers

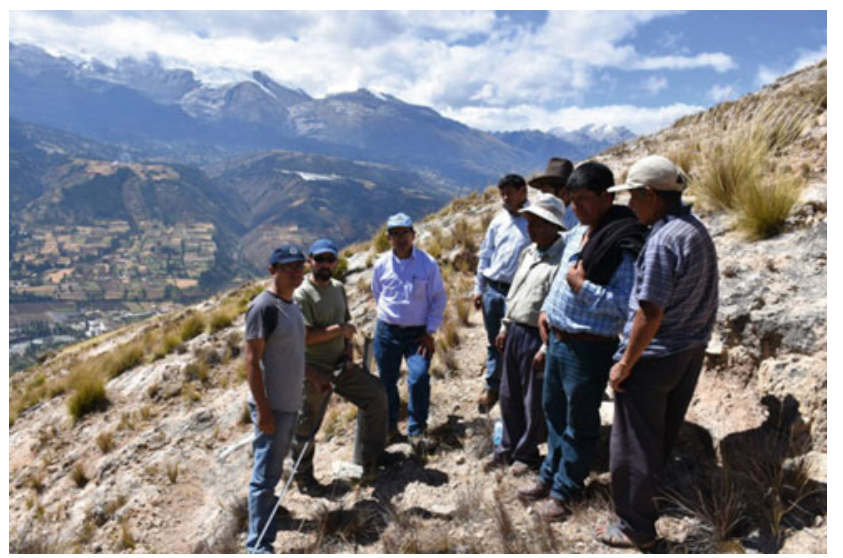

Fig. 4 Explanations of the technique of tape extensometric measurements to the Rampac Grande authorities were conducted in the field with the participation of Peruvian and Czech experts

\section{Knowledge Dissemination in the Czech Republic}

We conducted a variety of activities to bring landslide knowledge to the broader public. One of them is online-a publically available archive of historical photographs of Prof. Quido Záruba (https://www.irsm.cas.cz/index_en.php? page=Archiv_qz_en). The archive recently contains 8000 photographs, with some dating back to the 1920s during the 20th century, showing unique images of different geological features and engineering structures, including landslides and landslide-related mitigation works.
We organized several worshops and an international conference dedicated to bringing recent scientific knowledge to the Cezch experts and local authorities responsible for landslide mitigation. We also participated in the preparation of a documentary movie dedicated to landslide processes, which is aimed at explaining the basic information about landslide hazards and risk in the Czech Republic to a wide audience.

Acknowledgements This work was carried out thanks to the support of the long-term conceptual development research organization RVO: 67985891 and financial support of the INGO II project of the Ministry of Education No. LG15007.

\section{References}

Blahůt J, Rowberry M, Balek J, Klimeš J, Baroň I, Martí X (submitted) Monitoring giant landslide detachment planes in the era of big data analytics. In: Proccedings of the 4thWLF, 29 May-2 June 2017. Ljubljana, Slovenia

Emmer A, Vilímek V (2014) New method for assessing the susceptibility of glacial lakes to outburst floods in the Cordillera Blanca. Peru Hydrol Earth Sys Sci 18:3461-3479

Emmer A, Vilímek V, Huggel C, Klimeš J, Schaub Y (2016) Limits and challenges of compiling and developing a database of glacial lake outburst floods (IPL project No. 179). Landslides. doi:10.1007/ s10346-016-0686-6

Klimeš J, Vilímek V (2011) A catastrophic landslide near Rampac Grande in the Cordillera Negra, northern Peru. Landslides 8:309320

Klimeš J, Rowberry MD, Blahůt J, Briestenský M, Hartvich F, Košták B, Rybáŕ J, Stemberk J, Štěpančíkova P (2012) The monitoring of slow-moving landslides and assessment of stabilisation measures using an optical-mechanical crack gauge. Landslides 9:407-415. doi:10.1007/s10346-011-0306-4

Klimeš J, Yepes J, Becerril L, Kusák M, Galindo I, Blahut J (2016a) Development and recent activity of the San Andrés landslide on El Hierro, Canary Islands, Spain. Geomorphol 261:119-131

Klimeš J, Novotný J, Novotná I, Jordán de Urries B, Vilímek V, Emmer A, Strozzi T, Kusák M, Rapre A C, Hartvich F, Frey H (2016b) Landslides in moraines as triggers of glacial lake outburst floods: example of the Palcacocha Lake (Cordillera Blanca, Peru). Landslides. doi:10.1007/s10346-016-0724-4

Košták B (1969) A new device for in situ movement detection and measurement. Exp Mech 9:374-379

Pánek T, Klimeš J (2016) Temporal behavior of deep-seated gravitational slope deformations: A review. Earth Sci Rev 156:14-38

Pánek T, Hartvich F, Jankovská V, Klimeš J, Tábořík P, Bubík M, Smolková V, Hradecký J (2014) Large Late Pleistocene landslides from the marginal slope of the Flysch Carpathians. Landslides 11:981-992. doi:10.1007/s10346-013-0463-8

Rowberry MD, Kriegner D, Holy V, Frontera C, Llull M, Olejnik K, Marti X (2016) The instrumental resolution of a moire extensometer in light of its recent automatisation. Measurement 91:258-265 
Smolíková J, Blahůt J, Vilímek V (2016) Analysis of rainfall preceding debris flows on the Smědavská hora Mt., Jizerské hory Mts., Czech Republic. Landslides 13:683-696. doi:10.1007/s10346-0150601-6

Stemberk J, Hartvich F, Blahůt J, Rybáŕ J, Krejčí O (in press) Tectonic strain changes affecting the development of deep seated gravitational slope deformations in the Bohemian Massif and Outer Western Carpathians. Geomorphol
Vařilová Z, Kropáček J, Zvelebil J, Štastný M, Vilímek V (2015) Reactivation of mass movements in Dessie graben, the example of an active landslide area in the Ethiopian Highlands. Landslides 12:985-996

Vilímek V, Klimeš J, Torres MZ (2016) Reassessment of the development and hazard of the Rampac Grande landslide, Cordillera Negra. Peru Geoenviron Disasters 3:5. doi:10.1186/ s40677-016-0039-8
Open Access This chapter is licensed under the terms of the Creative Commons Attribution 4.0 International License (http:// creativecommons.org/licenses/by/4.0/), which permits use, sharing, adaptation, distribution and reproduction in any medium or format, as long as you give appropriate credit to the original author(s) and the source, provide a link to the Creative Commons license and indicate if changes were made.
The images or other third party material in this chapter are included in the chapter's Creative Commons license, unless indicated otherwise in a credit line to the material. If material is not included in the chapter's Creative Commons license and your intended use is not permitted by statutory regulation or exceeds the permitted use, you will need to obtain permission directly from the copyright holder. 